\title{
An alternative perspective on South Africa's public debt, 1962-1994
}

\author{
Estian Calitz, Stan du Plessis and Krige Siebrits
}

\section{Stellenbosch Economic Working Papers: 19/10 \\ Version: $27 / 10 / 2010$}

\begin{abstract}
KEYWORDS: SOUTH AFRICAN PUBLIC DEBT, FISCAL DISCIPLINE, ACCRUAL CLASSIFICATION, PENSION FUND DEFICITS, SUB-NATIONAL DEBT
\end{abstract}

\author{
JEL: H62, H63, G23
}

ESTIAN CALITZ DEPARTMENT OF ECONOMICS UNIVERSITY OF STELLENBOSCH

PRIVATE BAG X1, 7602 MATIELAND, SOUTH AFRICA E-MAIL: CALITZ@SUN.AC.ZA
STAN DU PLESSIS DEPARTMENT OF ECONOMICS UNIVERSITY OF STELLENBOSCH PRIVATE BAG X1, 7602 MATIELAND, SOUTH AFRICA E-MAIL: STAN@SUN.AC.ZA
KRIGE SIEBRITS DEPARTMENT OF ECONOMICS UNIVERSITY OF STELLENBOSCH

PRIVATE BAG X1, 7602

MATIELAND, SOUTH AFRICA E-MAIL:KRIGESIEBRITS@SUN.AC.ZA

A WORKING PAPER OF THE DEPARTMENT OF ECONOMICS AND THE BUREAU FOR ECONOMIC RESEARCH AT THE UNIVERSITY OF STELLENBOSCH 


\title{
An alternative perspective on South Africa's public debt, 1962-1994
}

\author{
Estian Calitz, Stan du Plessis and KRige Siebrits ${ }^{1}$
}

ABSTRACT

The history of public debt reflects the cumulative effect of fiscal decisions and real outcomes in the economy. In the South African case the published record on public debt distorts the historical perspective on the associated fiscal decisions. This note shows the impact of adjusting the South African public debt on an accrual basis to take account of two major obligations assumed in the first half of the 1990s, namely actuarial pension fund deficits and government debt of the apartheid homelands. The adjusted series is less volatile and rose less steeply between 1989 and 1996 than the official, cash based debt series. Failing to account for the evolution of these obligations exaggerates the impression of weak fiscal discipline in the early nineties and exemplary fiscal prudence in preceding decades.

Keywords: South African public debt, fiscal discipline, accrual classification, pension fund deficits, sub-national debt

JEL codes: H62, H63, G23

\footnotetext{
${ }^{1}$ Department of Economics, University of Stellenbosch. The authors thank the following persons for their much appreciated inputs and comments: Mara Boshoff, Faffa Knoetze, Michael Kock, Jac Laubscher, Frans le Roux, Kobus Reynecke and Ben Smit. As usual, the authors remain responsible for all errors.
} 


\section{INTRODUCTION}

The political transition in South Africa during 1994 took place against a backdrop of high government deficits (which peaked at 7.3\% of GDP in 1992/93) and a public debt burden that was rising alarmingly (national government debt rose from $36.4 \%$ on 31 March 1989 to a peak of $49.5 \%$ of GDP on 31 March 1996). So precipitous was this trend that economists at the time, and in subsequent years, feared the onset of a debt trap (for example, Van der Merwe 1993 and Cronje 1998, and the concerns raised in Fourie and Burger, 2003). Furthermore, it was widely ascribed to "weak" "aggregate fiscal discipline", in the words of Ajam and Aron (2007: 746). In this note we revisit this issue and illustrate how a revised calculation of the evolution of South African public debt since the 1960s leads to different conclusions. We base our calculations on the accrual of obligations by the government employees pension fund (GEPF), as adjusted to include imputed membership to employees in the former TBVC states (Transkei, Bophuthatswana, Venda and Ciskei) and self-governing territories (SGT) before 1994, as well as the accrual of public debt in those jurisdictions prior to 1994. The adjusted data suggest that the sense of imminent crisis during the mid-1990s and the harsh judgement on pre-1994 fiscal discipline requires revision.

We begin with a short historical context, followed by an outline of the method and calculations and conclude with our interpretation.

\section{HISTORICAL CONTEXT}

By 1994 government debt was just shy of 50\% of GDP - a dramatic increase from 31.5\% in 1990 which has been attributed partly to cyclical factors (Calitz \& Siebrits, 2003: 58-60). However, between 1989 and 1994, the Government accepted responsibility for two major obligations, namely the improved actuarial funding of the GEPF ${ }^{2}$ and the accumulated debts of the apartheid era's TBVC states and SGTs, as they were referred to at the time. While the consolidation of these obligations on the books of the national government occurred over a few years in the early nineties (see table 1 for the schedule and amounts ${ }^{3}$ ), the associated liabilities were incurred over a much longer period.

\footnotetext{
${ }^{2}$ These were not the only pension fund obligations, but the impact of the others was not as large. A closed pension fund (amounting to about R1bn) was established for retiring politicians in the apartheid political system. The pension fund for associated institutions was also underfunded and various institutions (e.g. universities) opted to establish their own pension funds; thus relieving government of the funding obligation. The pension fund for temporary workers was also underfunded.

${ }^{3}$ Table 1 shows the transfer payments to the GEPF between 1990 and 1994, as well as the budget balances of the TBVC states and SGTs and the transfer of their debt to the national Government between 1977 and 1994.
} 
Table 1: Transfers to GEPF; budget deficits in TBVC \& SGTs and debt taken over by the national government

\begin{tabular}{|c|c|c|c|c|}
\hline \multirow[b]{2}{*}{$\begin{array}{l}\text { Year ending } \\
31 \text { December }\end{array}$} & \multirow{2}{*}{$\begin{array}{c}\text { Additional } \\
\text { transfers to } \\
\text { GEPF(1)(2) }\end{array}$} & \multicolumn{3}{|c|}{ TBVC \& SGT } \\
\hline & & $\begin{array}{c}\text { Year ending } 31 \\
\text { March }\end{array}$ & $\begin{array}{c}\text { Budget } \\
\text { balances(3)(4) }\end{array}$ & $\begin{array}{c}\text { Debt transferred to } \\
\text { national } \\
\text { government }\end{array}$ \\
\hline & $\mathrm{Rm}$ & & $\mathrm{Rm}$ & $\mathrm{Rm}$ \\
\hline 1962 & 0.00 & 1962 & - & \\
\hline 1963 & 1.00 & 1963 & - & \\
\hline 1964 & 0.00 & 1964 & - & \\
\hline 1965 & 0.00 & 1965 & - & \\
\hline 1966 & 0.00 & 1966 & - & \\
\hline 1967 & 17.00 & 1967 & - & \\
\hline 1968 & 0.00 & 1968 & - & \\
\hline 1969 & 5.00 & 1969 & - & \\
\hline 1970 & 0.00 & 1970 & - & \\
\hline 1971 & 0.00 & 1971 & - & \\
\hline 1972 & 0.00 & 1972 & - & \\
\hline 1973 & 0.50 & 1973 & - & \\
\hline 1974 & 0.00 & 1974 & - & \\
\hline 1975 & 0.50 & 1975 & - & \\
\hline 1976 & 0.75 & 1976 & -12.00 & \\
\hline 1977 & 0.75 & 1977 & 46.00 & \\
\hline 1978 & 0.50 & 1978 & 93.00 & \\
\hline 1979 & 0.75 & 1979 & -46.00 & \\
\hline 1980 & 0.00 & 1980 & 6.00 & \\
\hline 1981 & 0.00 & 1981 & 47.00 & \\
\hline 1982 & 0.00 & 1982 & 66.00 & \\
\hline 1983 & 0.00 & 1983 & 291.00 & \\
\hline 1984 & 0.00 & 1984 & 244.00 & \\
\hline 1985 & 0.00 & 1985 & 434.00 & \\
\hline 1986 & 0.00 & 1986 & 561.00 & \\
\hline 1987 & 0.00 & 1987 & 1425.00 & \\
\hline 1988 & 0.00 & 1988 & 1381.00 & \\
\hline 1989 & 150.00 & 1989 & 555.00 & \\
\hline 1990 & 1000.00 & 1990 & 821.25 & \\
\hline 1991 & 1000.00 & 1991 & unknown & \\
\hline 1992 & 2000.00 & 1992 & unknown & \\
\hline 1993 & 7300.00 & 1993 & unknown & \\
\hline 1994 & 0.00 & 1994 & unknown & \\
\hline 1995 & 0.00 & 1995 & - & 14093.00 \\
\hline
\end{tabular}

Source: Transfers to pension funds and debt transferred to National Government: RSA Auditor-General Reports and RSA Budget Reviews, various issues; Budget balances, TBVC \& SGS: $S A R B(1991)$.

(1) It is not always clear from government documents wbich of the pension funds benefitted from the transfers. Given two sets of consolidation of pension funds, i.e. in 1973 and 1996 , eventually resulting in the GEPF, we regarded the GEPF as the beneficiary.

(2) Over and above the annual contributions as employer.

(3) A negative figure indicates a budget surplus.

(4) Figures for 1991-1994 bave not been published separately by the SA Reserve Bank. and merely included as part of the borrowing requirements of extra-budgetary institutions.

An accurate assessment of "aggregate fiscal discipline" would take account of the evolution of these

liabilities and our focus is on the financing commitments of government with regard to the funding of the

GEPF between 1962 and 1994, as well as the national consolidation of the debt accumulated by the

TBVC states and SGTs of the apartheid era in 1994. The argument is not that all contingent liabilities

should be counted as debt; rather we argue that the evolution of obligations that were converted abruptly into national debt is important if the debt stock is used as a barometer of fiscal discipline. Failing to account for the evolution of these obligations exaggerates the impression of weak fiscal discipline in the early nineties and exemplary fiscal prudence in preceding decades.

\section{METHOD AND CALCULATIONS}

In this section we describe the adjustment of public debt in terms of an accrual definition which reflects when the funding obligations for the GEPF, TBVC states and SGTs arose, rather than a cash definition which reflects when the actual financing was undertaken. Where the GEPF is concerned, if for any 
government employee the annual contribution to the pension fund is lower than the value of his/her accrued benefit in that year, the government incurs an unfunded liability. ${ }^{4}$ The South African government incurred unfunded liabilities of this kind over an extended period. Also, most of the debt of the TBVC states and SGTs which became national debt in 1994 was incurred during earlier years. In both these cases, therefore, there is retrospectively a time difference between date of funding and date of accrual of obligation, which renders the published national government debt series correct from a funding point of view but incorrect from the point of view of the time incidence of obligations.

Starting with the pension fund, the preferred method to estimate government's funding obligations with regard to the $\mathrm{GEPF}^{5}$ as it accrued over time would be to use the actuarial valuations of the government pension fund in selected years. However, such valuations do not exist or are not available, because of the ruling by the Minister of Social Welfare and Pensions in 1975 that periodic actuarial valuations were no longer needed (RSA, 1977: 75-76), as well as the decision ten years later by the Minister of National Health and Population Development not to release an actuarial report on the fund (Wassenaar, 1987: 1213).

As a pragmatic alternative we calculate the unfunded liabilities with respect to the pension fund by using the known levels of funding for the pension fund at particular dates, the time series of employer and

\footnotetext{
${ }^{4}$ A comprehensive actuarial analysis would take account of changes in life expectancy. Our method assumes no change over the period under review.

${ }^{5}$ Two consolidations of pension funds should be noted. As of 1 July 1973 the following were incorporated into the Government Service Pension Fund: the Public Service Pension Fund, the Permanent Force Pension Fund, the SA Police and Prisons Fund, the Government Service Widows' Pension Fund and two smaller funds. To ensure comparability with the post 1973 figures, we added data in respect of the four above-mentioned funds for the pre1973 period. To ensure comparability with the Government Employees Pension Fund, as consolidated in 1996, we added estimates of the contributions of employees and employers in the TBVC-states and SGTs for the period between 1973 and 1996.
} 
Table 2: Impact on the public debt-GDP ratio of applying accrual accounting to pension fund obligations

\begin{tabular}{|c|c|c|c|c|c|c|c|c|c|c|c|}
\hline Year & $\begin{array}{c}\text { Pension } \\
\text { fund } \\
\text { contri- } \\
\text { butions } \\
\text { by } \\
\text { members } \\
\text { (1) }\end{array}$ & $\begin{array}{l}\text { Pension } \\
\text { fund } \\
\text { contri- } \\
\text { butions } \\
\text { by } \\
\text { govt(1)(2) }\end{array}$ & $\begin{array}{c}\text { Remune- } \\
\text { ration, } \\
\text { incl } \\
\text { estimates } \\
\text { of TBVC } \\
\& \\
\text { SGTs(1)(3) }^{(1)}\end{array}$ & $\begin{array}{l}\text { Ratio } \\
\text { of } \\
\text { govt } \\
\text { to } \\
\text { mem- } \\
\text { ber } \\
\text { contri- } \\
\text { bu- } \\
\text { tions }\end{array}$ & $\begin{array}{l}\text { Total } \\
\text { contri- } \\
\text { bution } \\
\text { as } \% \text { of } \\
\text { remune- } \\
\text { ration }\end{array}$ & $\begin{array}{c}\text { Shortfall } \\
\text { on } \\
16.75 \% \\
\text { contri- } \\
\text { bution, } \\
\text { as } \% \text { of } \\
\text { remune- } \\
\text { ration }\end{array}$ & $\begin{array}{c}\text { Extra } \\
\text { contri- } \\
\text { butions } \\
\text { required } \\
\text { for } \\
\text { contribu- } \\
\text { tion rate } \\
\text { of } \\
16.75 \%(4) \\
\text { (5) }\end{array}$ & $\begin{array}{l}\text { Extra } \\
\text { pension } \\
\text { fund govt } \\
\text { contri- } \\
\text { butions } \\
\text { made } \\
\text { from time } \\
\text { to time }\end{array}$ & $\begin{array}{l}\text { Net extra } \\
\text { contri- } \\
\text { butions } \\
\text { required to } \\
\text { fill ratio gap } \\
\text { of } 16.75 \%\end{array}$ & $\begin{array}{c}\text { Accumu- } \\
\text { lated net } \\
\text { extra govt } \\
\text { contri- } \\
\text { butions to } \\
\text { effect } \\
16.75 \% \\
\text { ratio(6) }\end{array}$ & $\begin{array}{c}\text { Accu- } \\
\text { mulated } \\
\text { impact } \\
\text { on } \\
\text { debt- } \\
\text { GDP } \\
\text { ratio } \\
(7)\end{array}$ \\
\hline & (1) & (2) & (3) & (4) & $\begin{array}{c}(5)= \\
(2) /(3)\end{array}$ & $\begin{array}{c}(6)= \\
16.75- \\
\text { figures in } \\
(5)\end{array}$ & $\begin{array}{c}(7)=(3) * \\
(6) / 100\end{array}$ & (8) & $\begin{array}{c}(9)= \\
(7)-(8)\end{array}$ & (10) & (11) \\
\hline & $\mathrm{Rm}$ & $\mathrm{Rm}$ & $\mathrm{Rm}$ & & $\%$ & $\%$ & $\mathrm{Rm}$ & $\mathrm{Rm}$ & $\mathrm{Rm}$ & $\mathrm{Rm}$ & $\begin{array}{c}\text { Percen- } \\
\text { tage } \\
\text { points }\end{array}$ \\
\hline 1962 & 15.35 & 15.34 & 341.29 & 1.00 & 8.99 & 7.76 & 26.48 & 0.00 & 26.48 & (8) 82.74 & 1.40 \\
\hline 1963 & 16.68 & 16.67 & 373.01 & 1.00 & 8.94 & 7.81 & 29.13 & 1.00 & 28.13 & 116.14 & 1.78 \\
\hline 1964 & 18.92 & 18.91 & 411.43 & 1.00 & 9.20 & 7.55 & 31.08 & 0.00 & 31.08 & 154.58 & 2.15 \\
\hline 1965 & 20.95 & 20.95 & 430.88 & 1.00 & 9.72 & 7.03 & 30.27 & 0.00 & 30.27 & 195.95 & 2.49 \\
\hline 1966 & 22.34 & 22.33 & 492.65 & 1.00 & 9.07 & 7.68 & 37.85 & 0.00 & 37.85 & 248.99 & 2.91 \\
\hline 1967 & 24.57 & 25.82 & 541.16 & 1.05 & 9.31 & 7.44 & 40.26 & 17.00 & 23.26 & 289.95 & 3.03 \\
\hline 1968 & 28.07 & 29.41 & 595.62 & 1.05 & 9.65 & 7.10 & 42.28 & 0.00 & 42.28 & 353.83 & 3.42 \\
\hline 1969 & 22.89 & 38.66 & 643.39 & 1.69 & 9.57 & 7.18 & 41.22 & 5.00 & 41.22 & 420.73 & 3.61 \\
\hline 1970 & 26.38 & 44.89 & 773.98 & 1.70 & 9.21 & 7.54 & 58.38 & 0.00 & 58.38 & 516.23 & 4.04 \\
\hline 1971 & 30.74 & 52.36 & 928.96 & 1.70 & 8.94 & 7.81 & 72.51 & 0.00 & 72.51 & 638.79 & 4.52 \\
\hline 1972 & 36.09 & 61.87 & 1006.20 & 1.71 & 9.73 & 7.02 & 70.59 & 0.00 & 70.59 & 767.04 & 4.81 \\
\hline 1973 & 38.81 & 66.08 & 1259.59 & 1.70 & 8.33 & 8.42 & 106.09 & 0.50 & 105.59 & 942.45 & 4.77 \\
\hline 1974 & 62.29 & 128.12 & 1514.51 & 2.06 & 12.57 & 4.18 & 63.28 & 0.00 & 63.28 & 1101.27 & 4.54 \\
\hline 1975 & 75.60 & 167.76 & 1751.58 & 2.22 & 13.89 & 2.86 & 50.53 & 0.50 & 49.53 & 1265.88 & 4.63 \\
\hline 1976 & 79.83 & 184.15 & 1960.94 & 2.31 & 13.46 & 3.29 & 64.47 & 0.75 & 63.72 & 1475.85 & 4.78 \\
\hline 1977 & 91.68 & 220.53 & 2125.21 & 2.41 & 14.69 & 2.06 & 43.76 & 0.75 & 43.01 & 1681.23 & 4.91 \\
\hline 1978 & 101.54 & 253.86 & 2357.53 & 2.50 & 15.07 & 1.68 & 39.49 & 0.50 & 38.98 & 1887.43 & 4.79 \\
\hline 1979 & 143.91 & 377.51 & 2751.29 & 2.62 & 18.95 & -2.20 & -60.58 & 0.75 & -61.33 & 1996.30 & 4.24 \\
\hline 1980 & 165.48 & 446.66 & 3464.43 & 2.70 & 17.67 & -0.92 & -31.85 & 0.00 & -31.85 & 2196.44 & 3.50 \\
\hline 1981 & 208.67 & 584.49 & 4382.06 & 2.80 & 18.10 & -1.35 & -59.17 & 0.00 & -59.17 & 2422.17 & 3.33 \\
\hline 1982 & 278.06 & 705.86 & 5294.52 & 2.54 & 18.58 & -1.83 & -97.09 & 0.00 & -97.09 & 2588.05 & 3.14 \\
\hline 1983 & 355.10 & 901.79 & 6196.62 & 2.54 & 20.28 & -3.54 & -218.96 & 0.00 & -218.96 & 2692.23 & 2.85 \\
\hline 1984 & 430.98 & 1094.70 & 8091.01 & 2.54 & 18.86 & -2.11 & -170.43 & 0.00 & -170.43 & 2931.84 & 2.65 \\
\hline 1985 & 569.54 & 1480.02 & 9352.43 & 2.60 & 21.91 & -5.16 & -483.02 & 0.00 & -483.02 & 2891.82 & 2.27 \\
\hline 1986 & 627.77 & 1642.57 & 11804.33 & 2.62 & 19.23 & -2.48 & -293.12 & 0.00 & -293.12 & 2995.26 & 2.00 \\
\hline 1987 & 773.09 & 2027.43 & 14572.21 & 2.62 & 19.22 & -2.47 & -359.68 & 0.00 & -359.68 & 3043.04 & 1.74 \\
\hline 1988 & 983.49 & 2584.13 & 17242.29 & 2.63 & 20.69 & -3.94 & -679.53 & 0.00 & -679.53 & 2758.45 & 1.32 \\
\hline 1989 & 1108.28 & 2912.71 & 22165.29 & 2.63 & 18.14 & -1.39 & -308.31 & 150.00 & -458.31 & 2664.71 & 1.06 \\
\hline 1990 & 1312.53 & 3458.99 & 26694.20 & 2.64 & 17.87 & -1.12 & -300.24 & 1000.00 & -1300.24 & 1582.24 & 0.55 \\
\hline 1991 & 1462.41 & 3852.83 & 27694.86 & 2.63 & 19.19 & -2.44 & -676.34 & 1000.00 & -1676.34 & -109.78 & -0.03 \\
\hline 1992 & 1675.17 & 4411.52 & 32106.73 & 2.63 & 18.96 & -2.21 & -708.81 & 2000.00 & -2708.81 & -3238.55 & -0.87 \\
\hline 1993 & 1758.49 & 4640.66 & 36092.84 & 2.64 & 17.73 & -0.98 & -353.59 & 7300.00 & -7653.59 & -12236.24 & -2.87 \\
\hline 1994 & 1930.18 & 5289.85 & 44371.07 & 2.74 & 16.27 & 0.48 & 212.12 & 0.00 & 212.12 & -14044.17 & -2.91 \\
\hline
\end{tabular}

Sources: Various issues of SA Statistics, published by Statistics South Africa; Auditor-General Reports (various issues); RSA 1992 Budget Review, p 5.8; SA Reserve Bank. Quarterly Bulletin, various issues

(1) Data from the former TBVC-states and SGTs are included from June 1994 onwards in Statistics South Africa series. Before 1994 estimates were made by applying RS A transfers growth rates.

(2) Total of funding deficits in respect of the following pension funds which were later on consolidated into what is presently known as the Government Employee Pension Fund: Public Service Pension Fund, Permanent Force Pension Fund, SA police and Prisons Pension Fund. The surplus in the Government Service Widows Fund was also added. Valuations as on 31 March 1963. Source: Auditor-General Annual Reports.

(3) Remuneration data for the period 1990 to 2008 (the post-1989 series) are from the Survey of Employment and Earnings (P0275), published by Statistics South Africa. The pre-1991 series (up to 1990) showed a break, with the post 1989 series. Continuity was achieved by scaling up the pre-1991 series with the ratio between the two series' 1990 figures.

(4) The interest on accumulated debt was calculated at the yield rate on long-term government bonds.

(5) In the published series employer contributions to funds were excluded for years prior to 1992 and included thereafter. In order to calculating the required additional funding consistently, employer contributions were subtracted from remuneration as from 1992.

(6) Accumulated debt, bearing interest equal to average yield on government bonds for each year.

(7) Calculated, using data from SA Reserve Bank. Quarterly Bulletin, various issues.

(8) Actuarial shortage in four funds of R82.74m as on 31-03-1963, calculated from AG report, used as starting value. The shortfall of $\mathrm{R} 2648 \mathrm{~m}$ calculated for 1962 in column (7) is thus assumed to be part of the R82.74m.

employee contributions to the GEPF and an assumption on the appropriate level of contributions in a fully funded defined benefits scheme of this kind. The period under consideration runs from 1962 until 1994. We use 1962 as our starting point because of the publication by the Controller and Auditor-General (1969) of the government's liabilities towards pension funds on account of an actuarial evaluation on 31 
March 1963. ${ }^{6}$ The aggregate actuarial liability amounted to R82.74 million ${ }^{7}$, which is shown as the debt obligation at the beginning of our calculation in table 2 (the first figure in column 10). The end point (1994) was chosen because it was the culmination of the political transition and the end of a period (since 1989) of major debt restructuring and improved funding of the government pension fund. Also, 1994 is close to the last actuarial evaluation of the government's pension funds during apartheid. The actuarial report dated 9 July 1992 calculated an actuarial funding level of 51 per cent, but nonetheless stated that the funding position of the GEPF was consistently improving and that, if the trend were to continue, the GEPF would attain full funding naturally (RSA 1992: 289). ${ }^{8}$ Table 2 summarises our analysis of the accumulated impact on the public debt ratio of accounting for pension fund obligations on an accrual basis. Columns (1) and (2) show the contributions by, respectively, members and government to the government pension funds. Column (3) shows the total remuneration of government employees and includes estimates for the TBVC states. The latter had to be included in order to construct data which would be comparable before and during 1976-1994, the period during which separate states were established by the apartheid regime. In (4) the ratio between the contributions by government and members is calculated and in (5) we show the total contribution by government and employees as a percentage of employees' total remuneration. The next column (6) contains an estimate of the shortfall in the total contribution to pension funds based on the premise that, as we explain later, an annual contribution equal to $16.75 \%$ of remuneration would have ensured full funding of the pension funds over the period under consideration. Then (in column 7) we present the money value of the shortfalls, which we calculate by applying the shortfall ratio to the annual remuneration in (3). The negative figures from 1979 onwards reflect contributions in excess of the $16.75 \%$ target ratio. At various points during the period under consideration government made ad hoc payments into the pension funds and these are shown in (8). We subtract this from the required amounts and show the net extra contributions required to fill the ratio gap of $16.75 \%$ in (9). The accumulated shortfall over the years represents a debt obligation which carried interest (calculated at the average annual yield on long-term government bonds). The full impact (debt plus interest), is shown in (10). The first figure in (10) is the actuarial shortfall in the four

${ }^{6}$ This was the first actuarial valuation published after the founding of the Republic of South Africa in 1961 and the calender year 1962 is closest to the valuation date. Actuarial estimates were published quite infrequently, as evidenced by the following valuation dates: 31 August 1956, 31 August 1957, 31 March 1963, 31 March 1968, 31 March 1970 and 31 March 1971. The valuation of 31 March 1963 was the only one covering all four the pension funds mentioned in footnote 3.

7 The total funding shortfall of R82.74 million consisted of the deficits of the Public Service Pension Fund, the Permanent Force Pension Fund and the SA Police and Prisons Pension Fund, as well as the surplus on the Government Service Widows Fund. All these funds were later consolidated into the GEPF.

8 An important factor in the improved funding prospects was the changes in the investment policy of the (then) Public Investment Commissioners (now the Public Investment Corporation), the entity responsible for the investment of the GEPF and other government funds. This inter alia entailed a reduction in the prescribed investment in government stock and a commensurate greater freedom to invest in shares, as well as the contracting of a number of portfolio investors to manage its investments. The last-day salary as basis for pension was replaced in 1996 by the average salary of the last two years before retirement and the pension buy-back option was made costneutral to the fund. The GEPF's annual report (Government Employee Pension Fund, various issues) (which can be obtained from the GEPF) showed that on 31 March 1998 it was 96.5\% funded and the 2003 actuarial report, discounting future pension increases, showed a $100 \%$ funding level. Subsequently the Fund remained at or close to the $100 \%$ funding level. 
major funds of R82.74m as on 31 March 1963, explained earlier and used as starting value. The shortfall of R26.48m calculated for 1962 in column (7) is thus assumed to be part of the R82.74m. The final column shows the accumulated required contributions (or the accumulated interest-bearing debt obligations) in (10) as a percentage of GDP, i.e. the accumulated impact on the public debt-GDP ratio.

We were unable to obtain exact information on the funding history of the TBVC pension funds and their funding levels upon amalgamation with the newly established GEPF on 1 May 1996. Information supplied by staff of the GEPF indicate that the Bophuthatswana pension fund was 103\% funded on amalgamation, the Transkei fund was $85 \%$ funded as on 31 March 1994, the Ciskei funding was more or less of the same order and the Venda fund was also underfunded. Salary hikes shortly before amalgamation may have been the reason for all or some of the shortages. Given that ours is an approximate analysis and that the personnel of the overfunded Bophuthatswana pension fund represented a small percentage of all national and provincial public employees in SA, the TBVC states and the SGTs (on "independence" in 1977 it was only $3 \%$ ), we assumed for purposes of our analysis that the trend of underfunded pension funds in respect of apartheid South Africa applied pari passu to all pension funds of the TBVC states and SGTs. In any case, from column 6 in table 2 it can be seen that most of the inadequate contribution to pension funds occurred before the first of the TBVC states, namely Transkei, was established in 1976.

A critical assumption for the method used here is the benchmark that, in a normal funded private sector pension fund, the combined contribution of members and the employer varies between 15 and 18 per cent of total salaries (Wassenaar, 1987: 55). Having been a contributory fixed benefit fund since its inception in 1934, however, the government pension fund historically provided more generous pension benefits than private-sector funds, especially because pensions were calibrated on the salary of the last working day ${ }^{9}$, public servants were able to buy back pension at particularly low cost and a gratuity was due over and above the pension benefit ${ }^{10}$. Given that actual contribution rates averaged about 17 per cent during 1992-1994 - the time of the positive actuarial report referred to above, as well as during the most recent 12 years (from 1997-2008) since the intensive funding effort between 1989 and 1994, we used 17 per cent of total salaries ${ }^{11}$ (or 16.75 per cent to be exact ${ }^{12}$ ) as the norm for the required annual

\footnotetext{
${ }^{9}$ As opposed to the salary for the final few years of employment.

${ }^{10}$ A private sector employee, by contrast, had the option to convert up to one-third of the pension benefit into a gratuity. If the private annuity benefit (inclusive of the conversion option) was comparable to the public annuity benefit (exclusive of the gratuity), the public employee's gratuity thus represented a net benefit. In the case of a public servant, the pension annuity was calculated as $1 / 55 \% \times \mathrm{n} \times \mathrm{S}$ (where $\mathrm{n}=$ number of pensionable years of employment and $\mathrm{S}=$ pensionable salary). The gratuity was $6.72 \% \mathrm{x} \mathrm{n} \mathrm{S}$. In combination the total benefit was thus equivalent to $1 / 40 \% \times \mathrm{n} \times \mathrm{S}$, compared to a total private-sector pension benefit of $1 / 50 \times \mathrm{n} \times \mathrm{S}$. The benefit of the public pensioner was thus $25 \%$ higher than that of a typical employee retiring from a private company. Put differently, the higher benefit resulted in a higher pension fund obligation for the government, given the relatively low employee contribution during the 1960s and most of the 1970s (see column 4 of table 2).

11 This translates into a norm of about $24 \%$ for the required combined contribution by government and employees as a percentage of pensionable salaries (which are normally about $75 \%$ of total salaries). This is close to the required contribution rate of $24.9 \%$ to fund benefits that accrue, as stated in the actuarial report of 9 July 1992 (AuditorGeneral, 1992: 289).
} 
contribution to the GEPF. ${ }^{13}$ The contributions ratio was not consistently met during the sample period (see column 6). Consequently, the accumulated net extra contribution required rose steadily over the period under consideration (column 10).

The evolution of the funding shortfalls (i.e. the funding or ratio gap) shown in table 2 is revealing. Firstly, though government pensions were never managed on a pay-as-you-go basis, they were considerably underfunded during the entire period under review, especially during the sixties and seventies, when benchmarked against a contribution rate which would be sufficient to ensure adequate funding for a normal private sector pension fund. Note the extent of the accumulated amount of this underfunding, as shown in rand terms in column 10 of table 2 and its impact on the debt-GDP ratio in column 11 . As a ratio of GDP the underfunding reached a peak in 1977, when contributions at the norm rate of 17 per cent would have resulted in a rise in the debt-to-GDP ratio of almost 5 percentage points.

Underfunding of this kind emerges when some combination of contributions by the employer and employees falls short of a prudent ratio of total earnings. In the case of the GEPF an interesting pattern emerges: during the early sixties government and its employees contributed on a one-for-one basis to the GEPF (see column 4) and their combined contributions fell far short of the prudent benchmark (see column 6). From 1969 onwards government apparently allowed a persistently lower contribution by public servants while progressively raising the employer contributions as can be seen in the rapid rise of the employer to employee contributions ratio over this period in column 4. It was only by 1979 that the total annual contribution to the pension funds exceeded the prudent ratio of 17 per cent, at which time the employer-member contribution ratio had reached 2.6:1 (the industry norm is 2:1).

It appears, therefore, that underfunding was due to contributions below the industry norm and, in particular, increasingly due to below norm contributions by members (i.e. government employees). The latter amounted to an increase in the implicit remuneration of public servants, ultimately at the cost of the taxpayer. In fact, government incurred most of the contingent liabilities represented by the underfunded pension funds during the period 1962 to 1975 . This can be seen in the $6^{\text {th }}$ column of table 2 , where the combined contribution gap was above 7 percentage points for the entire period between 1962 and 1973, after which it gradually fell, eventually to turn negative in 1979, signifying excess funding relative to the norm.

Part of the rise in public debt in the early 1990s was therefore not the result of profligacy shortly before the political transition in 1994, but to compensate for inadequately funded pension benefits during an

\footnotetext{
${ }^{12}$ At this rate and when adding the accrual-adjusted obligations in respect of the accumulated debt of the TBVC states and SGTs, the adjusted and unadjusted debt-to-GDP ratios are equated in 1994. By doing this we regard the historical imputation of accrued obligations to be completed. The TBVC and SGT consolidation was indeed completed. The once-off enhanced funding of pension funds was also completed.

${ }^{13}$ We thus assume that the additional pension fund contributions by the Government in the early 1990s, together with the changed investment policies and concomitant investment yields in respect of pension funds and the scaleddown pension benefits (see footnote 6), were sufficient to eliminate the accrued funding deficit.
} 
earlier period. In fact, the accumulated net government contributions turned out to be negative from 1991 to 1994, thus reducing the accumulated impact on the debt-GDP ratio (see the last four figures in columns 10 and 11). By undertaking the extra funding, government actually removed (or largely reduced) a liability with a real threat to future fiscal sustainability.

Next we consider the debt of the TBVC states and SGTs, amounting to R14.09bn, which was consolidated with the national debt in 1994 (RSA, 1994: 2.8). For this calculation an appropriate period starts in 1977 (the year after Transkei became the first of the TBVC states to obtain nominal independence from the apartheid state) and ends in 1994 (the end of the apartheid era, after which these entities again became part of the new South Africa). Table 3 summarises our analysis of the accumulated

Table 3: Impact on the public debt-GDP ratio when applying accrual accounting to TBVC-debt taken over by the national government

\begin{tabular}{|c|c|c|c|c|c|}
\hline $\begin{array}{c}\text { Calender } \\
\text { year }\end{array}$ & $\begin{array}{c}\text { TBVC \& } \\
\text { SGS } \\
\text { deficits }^{(1)} \\
\end{array}$ & $\begin{array}{c}\text { Implied } \\
\text { accumulated } \\
\text { interest- } \\
\text { bearing debt } \\
\text { accruing on } \\
\text { account of } \\
\text { TBVC \& } \\
\text { SGT budget } \\
\text { deficits }(2) \\
\end{array}$ & $\begin{array}{c}\text { TBVC debt } \\
\text { taken over } \\
\text { by national } \\
\text { govt } \\
\end{array}$ & $\begin{array}{l}\text { Net implied } \\
\text { accumulated } \\
\text { historical } \\
\text { debt } \\
\text { obligations }\end{array}$ & $\begin{array}{c}\text { Accumulated } \\
\text { impact on } \\
\text { debt-GDP } \\
\text { ratio } \\
\end{array}$ \\
\hline & $\begin{array}{l}(1) \\
\mathrm{Rm}\end{array}$ & $\begin{array}{l}(2) \\
\mathrm{Rm}\end{array}$ & $\begin{array}{l}\text { (3) } \\
\mathrm{Rm}\end{array}$ & $\begin{array}{c}(4)=(2)-(3) \\
\mathrm{Rm}\end{array}$ & $\begin{array}{l}(5) \\
\text { Percentage } \\
\text { points }\end{array}$ \\
\hline 1979 & -11 & 123 & 0 & 123 & 0.26 \\
\hline 1980 & -7 & 130 & 0 & 130 & 0.21 \\
\hline 1981 & 37 & 189 & 0 & 189 & 0.26 \\
\hline 1982 & 61 & 278 & 0 & 278 & 0.34 \\
\hline 1983 & 235 & 583 & 0 & 583 & 0.62 \\
\hline 1984 & 256 & 975 & 0 & 975 & 0.88 \\
\hline 1985 & 387 & 1608 & 0 & 1608 & 1.26 \\
\hline 1986 & 529 & 2463 & 0 & 2463 & 1.65 \\
\hline 1987 & 1209 & 4240 & 0 & 4240 & 2.43 \\
\hline 1988 & 1392 & 6573 & 0 & 6573 & 3.14 \\
\hline 1989 & 762 & 8497 & 0 & 8497 & 3.38 \\
\hline 1990 & 755 & 10728 & 0 & 10728 & 3.7 \\
\hline 1991 & 205 & 12755 & 0 & 12755 & 3.84 \\
\hline 1992 & 0 & 14655 & 0 & 14655 & 3.94 \\
\hline 1993 & 0 & 16464 & 0 & 16464 & 3.86 \\
\hline 1994 & 0 & 17846 & 14093 & 3753 & 0.78 \\
\hline
\end{tabular}

(1) F iscal year data converted by interpolation to calendar year data. No data could be obtained for the period 1991-1993 and the deficits were regarded as zero.

(2) Accumulated debt carries interest equal to average annual yield on long-term government bonds. Because debt was taken over by the national government towards the middle of the year, interest for 1994 was calculated for six months only.

impact on the public debt ratio of accounting for the debts of these regions on an accrual basis. Column 1 of table 3 shows the extent of annual deficits over time, as converted by interpolation to calendar year figures. Column 2 contains the implied accumulated interest-bearing debt if the SA government had financed the deficits in the years in which they occurred. (Surpluses as in 1979 and 1980, shown with negative signs, of course reduce the accrued debt.) Accrued debt calculations were based on the 
assumption that these debts were not redeemed and carried interest equal to average long-term South African government bond yields. In column 3 we show the amount of debt taken over by the SA government in 1994 and column 4 contains the net implied historical debt obligations on an accrual basis. Column 5 contains the accumulated impact on the public debt-GDP ratio. By the time the debt was taken over by the post-apartheid state, the accumulated impact was almost four percentage points (see the second last entry in column 5). ${ }^{14}$

Table 4: Official and accrual adjusted South African national government debt as \% of GDP, 1962-1994

\begin{tabular}{|c|c|c|c|c|c|}
\hline Year & $\begin{array}{c}\text { Official } \\
\text { debt-GDP ratio }\end{array}$ & $\begin{array}{c}\text { Accrual adjusted } \\
\text { debt-GDP ratio }\end{array}$ & Year & $\begin{array}{c}\text { Official } \\
\text { debt-GDP ratio }\end{array}$ & $\begin{array}{c}\text { Accrual adjusted } \\
\text { debt-GDP ratio }\end{array}$ \\
\hline & $\%$ & $\%$ & & $\%$ & $\%$ \\
\hline 1962 & 47.20 & 48.61 & 1979 & 38.61 & 43.11 \\
\hline 1963 & 44.24 & 46.02 & 1980 & 31.86 & 35.56 \\
\hline 1964 & 41.64 & 43.79 & 1981 & 29.90 & 33.50 \\
\hline 1965 & 42.32 & 44.81 & 1982 & 31.05 & 34.52 \\
\hline 1966 & 43.79 & 46.70 & 1983 & 31.48 & 34.95 \\
\hline 1967 & 42.45 & 45.49 & 1984 & 31.20 & 34.74 \\
\hline 1968 & 46.08 & 49.51 & 1985 & 30.24 & 33.77 \\
\hline 1969 & 43.74 & 47.35 & 1986 & 31.07 & 34.73 \\
\hline 1970 & 42.00 & 46.03 & 1987 & 31.75 & 35.92 \\
\hline 1971 & 42.54 & 47.06 & 1988 & 32.03 & 36.48 \\
\hline 1972 & 43.92 & 48.73 & 1989 & 32.23 & 36.67 \\
\hline 1973 & 38.03 & 42.80 & 1990 & 31.48 & 35.72 \\
\hline 1974 & 32.90 & 37.43 & 1991 & 34.51 & 38.32 \\
\hline 1975 & 36.94 & 41.58 & 1992 & 37.23 & 40.30 \\
\hline 1976 & 39.24 & 44.03 & 1993 & 41.44 & 42.44 \\
\hline 1977 & 40.78 & 45.78 & 1994 & 49.23 & 49.24 \\
\hline 1978 & 41.22 & 46.33 & & & \\
\hline
\end{tabular}

Source: SARB Quarterly Bulletin, various issues.

Adjusted figures calculated by the authors

Combining the information in tables 2 and 3 allows the adjustment on an accrual basis of the national debt from 1962 to 1994, expressed as a ratio of GDP in table 4. The adjusted figures show what the debt would have been if the shortfalls in pension fund contributions and the budget deficits in the TBVC-states and SGTs were added to the South African government's debt every year, that is, as and when they occurred. Figure 1 plots the adjusted and unadjusted (officially published) debt-GDP ratios as time series over the period under consideration.

\footnotetext{
${ }^{14}$ Our calculations show that in 1994 the entities' accumulated interest-bearing debt obligations on an accrual basis exceeded the total debt taken over by the national government by an amount of R3.75m (see last entry in column 3), thus leaving an impact of 0.78 percentage points of GDP after the debt take-over (last entry, column 5). This may be because by the time the debt was taken over by the SA government in 1994, not all of the accumulated deficits since 1978 represented outstanding debt, as initially assumed.
} 
Figure 1: South African national government debt as \% of GDP: official and accrual-adjusted, 1962-1994.

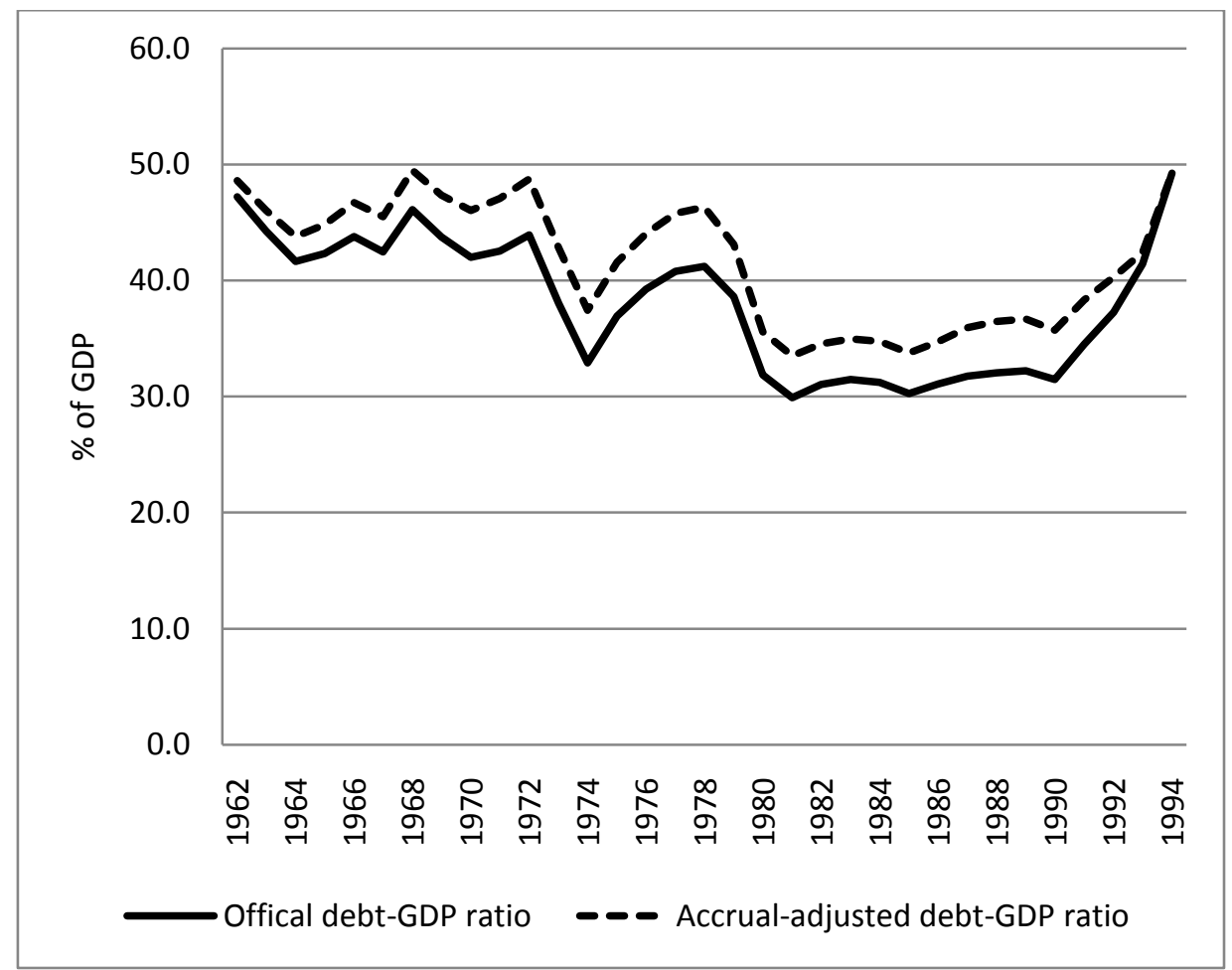

\section{INTERPRETATION}

In this note we reviewed the concerns about the sharp rise in the South African government debt as a percentage of GDP between 1989 and 1996. We developed an adjusted public debt series on an accrual basis. The outcomes of the exercise support a number of observations.

A substantial part of the cash debt that emerged towards the end of the apartheid regime had been incurred much earlier. By funding these debts explicitly the national government before and especially in 1994 assumed responsibility for unfunded obligations with a long history. The improved funding of the pension funds reduced, if not removed, a major liability that otherwise would have required financing in the future.

The removal of the debt of the TBVC states and SGTs closed the financial books on a failed system and enabled a fresh start for the new provinces.

The accrual accounting applied here indicates that the adjusted general level of public debt (on average $41.6 \%$ of GDP) was significantly higher during the period under review, than the cash debt figures showed (on average 38\%). By and large the difference between the adjusted and the official debt series averaged almost 4 percentage points over the period. But the adjusted (or accrual) series was less volatile than the "cash" series; their respective standard deviations are 5.4 and 6.1. In addition, the average annual 
rise in the accrual-based public debt series between 1989 and 1994 was also less steep than the official debt figures, namely 20.8 per cent compared to 23.9 per cent.

In conclusion, the published public debt record distorts the historical perspective on the associated fiscal decisions. This note shows the impact of adjusting the public debt on an accrual basis to take account of two major obligations assumed in the early 1990s, namely actuarial pension fund deficits and debt of apartheid homelands. Failing to account for the evolution of these obligations exaggerates the impression of weak fiscal discipline in the early nineties and exemplary fiscal prudence in preceding decades.

\section{REFERENCES}

Ajam, T. and J. Aron (2007). "Fiscal Renaissance in a Democratic South Africa." Journal of African Economies 16(5): 745-781.

Auditor-General (1992). Report of the Auditor-General for the Financial Year 1991-92. R.P. 148/1992. Pretoria: Government Printer.

Auditor-General (1977). Report of the Auditor-General for the Financial Year 1976-77, Part III. R.P. 82/1977. Pretoria: Government Printer.

Auditor-General. Report of the Auditor-General. Various issues. SA Reserve Bank: Government Printer.

Calitz, E. and F.K. Siebrits (2003). "Fiscal policy in the 1990s". The South African Journal of Economic History 18(1\&2): 50-75.

Controller and Auditor-General (1969). Part III of the Report of the Controller and Auditor-General for the Fiscal Year 1968-69 on the Appropriation Accounts and Miscellaneous Accounts and the Finance Statements. Pretoria.

Cronje, A. (1998). Deficit Financing and the Public Debt in South Africa: Some Unpleasant Fiscal Arithmetic. In Economic Globalization and Fiscal Policy, edited by I. Abedian and M. Biggs. Cape Town: Oxford University Press.

Department of Finance (1994). Begrotingsoorsig. Pretoria: Department of Finance. 22 June 1994.

Department of Finance (1992). Begrotingsoorsig, Pretoria: Department of Finance. 18 March 1992.

Fourie, F. C. v. N. and P. Burger (2003). "Fiscal Sustainability and the South African Transformation Challenge." South African Journal of Economics 71(4): 806-829.

Government Employee Pension Fund (GEPF). Annual Report (various issues). Pretoria. GEPF (available on request). SA Reserve Bank (1991). South Africa's public-sector accounts, 1973 to 1990. SARB Occasional Paper no 4. Pretoria.

SA Reserve Bank. Quarterly Bulletin (various issues). Pretoria: South African Reserve Bank.

Statistics South Africa. South African Statistics (various issues). Pretoria: Statistics South Africa.

Statistics South Africa. Survey of Employment and Earnings (P0275). Pretoria: Statistics South Africa.

Van der Merwe, E.J. (1993). Is South Africa in a debt trap? SA Reserve Bank Occasional Paper no 6. Pretoria. Wassenaar, A.D. (1987). En route to fairyland. Cape Town: Tafelberg. 